\title{
IDENTIFIKASI DAN PREVALENSI ENDOPARASIT (Gnathostoma sp.) PADA BELUT SAWAH (Monopterus albus) DENGAN UKURAN BERBEDA YANG DIKIRIM KELUAR PROVINSI KALIMANTAN SELATAN
}

\author{
(Identification and Prevalence of Endoparacytes (Gnathostoma sp.) in Paddy Eel (Monopterus \\ albus) with Different Sizes Throughout South Kalimantan Province)
}

\section{Lukman Mugiyarto, Elrifadah dan Mukhlisah}

Prodi Budi Daya Perairan, Fakultas Pertanian Univ. Achmad Yani Banjarmasin

Penulis Koresponden : elrifadah@uay.ac.id

Article Submitted: 07-07-2021

Article Accepted: 10-08-2021

\begin{abstract}
This study aims to determine the type of endoparasitic worm Gnathostoma sp and the prevalence that infects rice field eel (Monopterus albus) with different grades. the method used is descriptive method. Samples were taken from 3 different farm locations (Nor Aini, Banjar Regency, CV. Karya Bersama, Banjarbaru City, and Saberiannor Banjarbaru City), as many as 120 individuals with each grade (A, B, C, and D) totaling 30 individuals. Samples were examined using the microscopic method with 3 replications on each target organ, namely liver, meat, intestines, and kidneys. The results of the examination showed that Gnathostoma sp worm cysts were found, namely only in the liver, while in the intestines, flesh, and kidneys were not found. Based on the identification of Gnathostoma sp endoparasites seen from morphological characteristics, third stage larvae (L3) in the phylum Nematoda, cylindrical body shape, transparent body color, and blackish brown, head shape resembling a light bulb, mouth, and has anus at the end of its body. Prevalence value in grade $\mathrm{A}=40 \% ; \mathrm{B}=30 \% ; \mathrm{C}=40 \%$, and $\mathrm{D}=30 \%$, this includes the category commonly or ordinary which describes that the parasite usually infects fish with a prevalence value range of 30-49\%. It is still possible to send rice field eels outside of South Kalimantan Province, although the results of the examination of the test samples indicated the presence of the parasite infection Gnathostoma sp..
\end{abstract}

Keywords: identifikasi, prevalensi, gnasthostoma, monopterus albus

\section{PENDAHULUAN}

Belut termasuk jenis ikan air tawar yang banyak diperdagangkan dan hidup di Indonesia, terutama jenis Belut Sawah (Monopterus albus). Belut banyak dijumpai di perairan sungai atau rawa yang terdapat di pulau Sumatera, Jawa, Bali, Kalimantan Selatan, Sulawesi, Nusa Tenggara Timur, dan Nusa Tenggara Barat.

Belut memiliki serapan pasar yang sangat baik untuk konsumsi lokal maupun ekspor. Permintaan belut yang terus meningkat disebabkan masyarakat makin sering mengkonsumsi belut sebagai bahan lauk. Hal tersebut dikarenakan belut memiliki warna daging kemerahan, lembut, gurih saat dikonsumsi, serta memiliki nilai gizi dan sebagai sumber protein yang sangat tinggi. Beberapa negara seperti Jepang membutuhkan belut sekitar 400 ton/bulan, Hongkong 80 ton/bulan, China 40 ton/bulan, Korea Selatan dan Taiwan 32 ton/bulan, Singapura 24 ton/bulan, dan Malaysia 80 ton/bulan. Belut yang di ekspor ke negara tersebut biasanya dalam bentuk belut segar (fresh eels), belut asap (smoked eels), dan 
belut beku (frozen eels). (Roi, 2009 di dalam Djazuli, $d k k, 2012)$.

Berdasarkan data dari Balai Karantina Ikan dan Pengendalian Mutu Hasil Perikanan (Balai KIPM) Banjarmasin, belut yang dikirim keluar dari Provinsi Kalimantan Selatan baik melalui Bandara Syamsudin Noor dan Pelabuhan Trisakti Banjarmasin selama 4 (empat) tahun terakhir mengalami kenaikan. Pada tahun 2017 jumlah belut yang dikirim sebanyak 7.472.580 ekor dengan frekuensi 1.502 kali, tahun 2018 jumlah belut yang dikirim sebanyak 9.325.362 ekor dengan frekuensi 1.749 kali, tahun 2019 jumlah belut yang dikirim sebanyak 9.895.038 ekor dengan frekuensi 601 kali, tahun 2020 jumlah belut yang dikirim sebanyak 12.921 .703 ekor dengan frekuensi 604 kali.

Berdasarkan laporan dari Badan Karantina Ikan pada tahun 2011 terjadi penolakan ekspor belut asal Indonesia oleh Jepang dikarenakan positif Gnathostoma $s p$. Hasil analisis laboratorium menunjukkan semua Gnathostoma sp. yang ditemukan pada belut bersifat patogenik terhadap manusia (Lusiastuti, $d k k, \quad 2013$ ). Ditemukannya Gnathostoma sp. pada belut Indonesia tidak hanya membuat kerugian secara ekonomis, namun juga dapat menimbulkan potensi penyakit Gnathostomiasis pada manusia di Indonesia (Puspasari, 2013 di dalam Lusiastuti, dkk, 2013).

Kebutuhan informasi yang masih terbatas mengenai Gnathostoma sp. yang menginfeksi pada belut mendorong untuk dilakukan penelitian ini sehingga dapat diketahui identifikasi dari jenis parasit tersebut serta nilai prevalensi dari serangan parasit pada setiap ukuran belut sawah (Monopterus albus) yang berasal dari tangkapan alam di wilayah Kalimantan Selatan.

\section{METODE PENELITIAN}

\section{Tempat dan Waktu}

Penelitian ini dilaksanakan di Laboratorium Balai Karantina Ikan dan Pengendalian Mutu Hasil Perikanan (Balai KIPM) Banjarmasin di Kota Banjarbaru, selama 1 Bulan mulai tanggal 22 Maret-19 April 2021.

\section{Alat dan Bahan \\ Alat tulis, Disecting set, Cover glass, Obyek glass, Timbangan digital, nampan, Mikroskop trinokular, penggaris, plastik contoh uji, Alkohol 70\%, aquadest, belut sawah.}

\section{Metode}

Metode yang digunakan dalam penelitian ini adalah metode deskriptif yaitu data yang diperoleh digambarkan sebagaimana adanya tanpa membuat sebuah kesimpulan yang berlaku untuk umum (Sugiyono, 2008 di dalam Rokhmah, 2019). Pengambilan sampel lokasi (farm) ditentukan dengan menggunakan purposive sampling.Pengambilan sampel lokasi (farm) dilakukan di 3 (tiga) suplayer yang berbeda yang berada di wilayah Provinsi Kalimantan Selatan yaitu di farm Saberiannor yang berlokasi di Kota Banjarbaru, farm Nor Aini yang berlokasi di Kabupaten Banjar, dan farm CV. Karya Bersama yang berlokasi di Kota Banjarbaru. Ketiga tempat tersebut dipilih karena paling sering dan kontinyu dalam melakukan pengiriman belut sawah (Monopterus albus), paling banyak jumlah belut yang dikirim, dan wilayah pemasaran belut keluar Provinsi Kalimantan Selatan yang luas.

\section{Manajemen Penelitian}

1. Pengambilan Sampel (Contoh Uji)

Pengambilan sampel dilakukan dengan random sampling dan lethal sampling (teknik pemeriksaan sampel yang dilakukan dengan cara mematikan ikan sampel uji). Besarnya jumlah sampel yang diambil berdasarkan nilai asumsi prevalensi sebesar $20 \%$ (Keputusan Kepala BKIPM Nomor 
117, 2017). Jumlah contoh uji yang harus pada Tabel 1. diambil secara lethal sampling dapat di lihat

Tabel 1. Jumlah contoh uji yang harus diambil secara lethal sampling

\begin{tabular}{lccccccc}
\hline \multirow{2}{*}{$\begin{array}{c}\text { Ukuran Populasi } \\
\text { (n) }\end{array}$} & $2 \%$ & $5 \%$ & $10 \%$ & $20 \%$ & $30 \%$ & $40 \%$ & $50 \%$ \\
\cline { 2 - 7 } & 50 & 35 & 20 & 10 & 7 & 5 & 2 \\
100 & 75 & 45 & 23 & 10 & 9 & 7 & 6 \\
250 & 110 & 50 & 25 & 10 & 9 & 8 & 7 \\
500 & 130 & 55 & 26 & 10 & 9 & 8 & 7 \\
1.000 & 140 & 55 & 27 & 10 & 9 & 9 & 8 \\
1.500 & 140 & 55 & 27 & 10 & 9 & 9 & 8 \\
2.000 & 145 & 60 & 27 & 10 & 9 & 9 & 8 \\
4.000 & 145 & 60 & 27 & 10 & 9 & 9 & 8 \\
10.000 & 145 & 60 & 27 & 10 & 9 & 9 & 8 \\
$\geq 100.000$ & 150 & 60 & 30 & 10 & 9 & 9 & 8 \\
\hline
\end{tabular}

Sumber : Keputusan Kepala BKIPM Nomor 117 Tahun 2017

Sampel yang diambil belut sawah hidup, ukuran dan jumlah sampel tersebut dapat di lihat pada Tabel 2.

Tabel 2. Ukuran belut sawah (Monopterus albus) yang dijadikan sampel

\begin{tabular}{ccccc}
\hline Grade & $\begin{array}{c}\text { Jumlah } \\
\text { Ekor/Kg }\end{array}$ & $\begin{array}{c}\text { Berat Per Ekor } \\
(\text { Gram) }\end{array}$ & $\begin{array}{c}\text { Jumlah Sampel } \\
\text { (Ekor) }\end{array}$ & $\begin{array}{c}\text { Jumlah Sampel dari Tiga } \\
\text { Lokasi }\end{array}$ \\
\hline A & $2-6$ & $200-$ up & 10 & 30 \\
B & $7-9$ & 120 -up & 10 & 30 \\
C & $10-14$ & $75-$ up & 10 & 30 \\
D & $15-20$ & 50 -up & 10 & 30 \\
\hline \multicolumn{5}{c}{ Total belut yang telah diperiksa } \\
\hline
\end{tabular}

Keterangan : 'up' (ukuran berat ke atas)

Sumber : Suplayer Belut Sawah (Monopterus albus)

\section{Pemeriksaan Parasit}

Prosedur pemeriksaan parasit dilakukan mengikuti Instruksi Kerja Metode (IKM) Pemeriksaan Gnathostoma sp. yang dikeluarkan oleh Laboratorium Balai KIPM Banjarmasin Nomor Dokumen IKM/1.3/BKIBDJ tentang isolasi kista Gnathostoma sp pada ikan utuh secara konvensional.

Prosedur kerja tersebut antara lain :

a. Belut ditimbang dan diukur untuk mengetahui berat dan panjang dari belut tersebut b. Belut dimatikan dengan menusukkan jarum di kepala sehingga jaringan syaraf yang ada terputus.

c. Nekropsi pada belut dengan cara menyayat sepanjang garis perut bagian bawah.

d. Mengambil organ dalam belut seperti : usus, hati, ginjal, dan daging belut kemudian ditaruh dalam cawan petri. Apabila belut terinfeksi larva tahap ketiga (L3) cacing Gnathostoma sp akan tampak nodul-nodul putih kekuningan berupa fluid bladder / gelembung cairan pada hati, ginjal, dan daging belut. 
e. Nodul kecil berwarna putih kekuningan dikumpulkan dan diberi cairan aquades.

f. Nodul fluid bladder dipecahkan menggunakan cover glass di atas gelas objek namun jangan ditekan pada bagian kista tetapi cukup menekan dengan hati-hati pada bagian ujung dari cover glass. Langkah yang dilakukan selanjutnya yaitu dengan menusuk membran fluid bladder secara hati-hati menggunakan jarum dan mengeluarkan larva cacing Gnathostoma sp.

g. Larva cacing Gnathostoma sp. Kemudian diamati dibawah mikroskop menggunakan perbesaran 4x objektif hingga 40x objektif

h. Jumlah cacing Gnathostoma sp. yang ditemukan dalam setiap sampel yang diperiksa kemudian dicatat. Langkah tersebut berlaku juga pada setiap endoparasit lain yang ditemukan pada sampel belut.

\section{Parameter Pengamatan}

Parameter utama yang diamati adalah mengidentifikasi dan menghitung tingkat prevalensi endoparasit yang menginfeksi belut sawah dengan ukuran yang berbeda. Prevalensi merupakan besarnya persentase ikan yang terinfeksi dari ikan yang diperiksa. Prevalensi jenis endoparasit pada belut sawah dihitung dengan cara sebagai berikut (Hoffman, 1967 di dalam Kurniawan, 2016).

\section{Prevalensi $=\underline{\text { Jumlah Belut Sawah yang Terinfeksi Gnathostoma } s p} . \times 100 \%$} Jumlah Total Belut Sawah yang Diperiksa

Kategori prevalensi infestasi cacing endoparasit dapat di lihat pada Tabel 3.

Tabel 3. Kategori prevalensi infestasi cacing endoparasit

\begin{tabular}{llc}
\hline & Kategori Infestasi & Rentang Nilai (\%) \\
\hline Almost never & Tidak Pernah & $<0,01$ \\
Very rarely & Sangat Jarang & $<0,1-0,01$ \\
Rarely & Jarang & $<1-0,1$ \\
Occasionaly & Kadang-kadang & $1-9$ \\
Often & Sering & $10-29$ \\
Commonly & Biasa & $30-49$ \\
Frequenly & Sering Kali & $50-69$ \\
Usualy & Biasanya & $70-89$ \\
Almost always & Hampir Selalu & $90-98$ \\
Always & Selalu & $99-100$ \\
\hline
\end{tabular}

Sumber : Williams and Williams, (1996) di dalam Kurniawan, (2016).

\section{Analisis Data}

Data hasil identifikasi endoparasit yang menginfeksi belut sawah dianalisis secara deskriptif dan disajikan dalam bentuk gambar dan tabel.

Analisa deskriptif bertujuan untuk menyajikan dan menganalisa data agar memiliki makna dan bersifat komunikatif (Purwanto dan Dyah, 2017). Sedangkan nilai prevalensi endoparasit dihitung dan disajikan dalam bentuk tabel.

\section{HASIL DAN PEMBAHASAN}

Adapun data belut yang diikirim keluar Provinsi Kalimantan Selatan pada waktu pengambilan contoh uji dapat di lihat pada Tabel 4. 
Tabel 4. Data belut yang dikirim pada 3 (tiga) farm dengan grade yang berbeda

\begin{tabular}{|c|c|c|c|c|c|c|c|c|c|}
\hline \multirow[t]{2}{*}{ No } & \multirow[t]{2}{*}{ Farm } & \multicolumn{2}{|c|}{$\begin{array}{c}\text { Grade A } \\
\text { (2-6 ekor } / \mathrm{kg})\end{array}$} & \multicolumn{2}{|c|}{$\begin{array}{c}\text { Grade B } \\
(7-9 \text { ekor } / \mathrm{kg})\end{array}$} & \multicolumn{2}{|c|}{$\begin{array}{c}\text { Grade C } \\
(10-14 \text { kor } / \mathrm{kg})\end{array}$} & \multicolumn{2}{|c|}{$\begin{array}{c}\text { Grade D } \\
(15-20 \text { ekor/kg) }\end{array}$} \\
\hline & & $\mathrm{Kg}$ & Ekor & $\mathrm{Kg}$ & Ekor & $\mathrm{Kg}$ & Ekor & $\mathrm{Kg}$ & Ekor \\
\hline 1 & Nor Aini & 610 & 3.050 & 1.400 & 11.667 & 818 & 10.907 & 700 & 14.000 \\
\hline 2 & $\begin{array}{l}\text { CV. Karya } \\
\text { Bersama }\end{array}$ & 500 & 2.500 & 1.400 & 11.667 & 1.100 & 14.667 & 500 & 10.000 \\
\hline 3 & Saberiannor & 500 & 2.500 & 1.120 & 9.333 & 620 & 8.267 & 560 & 11.200 \\
\hline
\end{tabular}

Sumber : Data primer diolah (2021)

\section{Identifikasi Endoparasit Cacing Gnathostoma sp.}

Hasil pemeriksaan contoh uji pada organ dalam belut sawah dengan metode mikroskopis serta $3 \mathrm{x}$ ulangan pemeriksaan pada organ target dari setiap grade/ukuran belut ditemukan kista cacing Gnathostoma $s p$., yaitu pada organ hati. Sedangkan pada organ usus, daging, dan ginjal tidak ditemukan adanya infeksi cacing Gnathostoma sp. Hal ini sesuai dengan yang dijelaskan oleh Sugaroon et al. (2003) di dalam Khati $d k k$ (2013) bahwa infeksi tahap larva dari Gnathostoma sp. paling tinggi ditemukan pada hati. Hal tersebut dikarenakan larva tahap kedua (L2) yang masuk melalui saluran pencernaan akan menembus organ hati dan menyerap nutrisi serta dengan adanya mulut dan gigi yang runcing akan memudahkan cacing ini untuk menggigit, menghisap, dan menyerap sarisari makanan dari inangnya. Keberadaan larva di dalam organ hati akan menyebabkan peradangan dan juga abnormalitas sistem organ. Di dalam organ hati belut sawah tersebut larva tahap kedua (L2) cacing Gnathostoma sp. akan mengkista dan berkembang menjadi larva tahap ketiga (L3).

Gnathostoma sp. yang ditemukan pada penelitian ini merupakan larva stadium ketiga cacing Gnathostoma sp. (L3) dan masih dalam bentuk kista yang terdapat di dalam organ hati belut sawah. Kista Gnathostoma sp. tersebut ditemukan pada setiap ukuran grade mulai dari A, B, C, dan
D serta pada setiap lokasi farm pengambilan contoh uji.

Hasil identifikasi secara morfologi, cacing Gnathostoma sp. dideskripsikan sebagai berikut: Filum Nematoda, Kelas Secernentea, Ordo Spirurida, Family Gnatosthomatidae, Genus Gnathostoma, Spesies Gnathostoma sp. hal ini sesuai dengan Maleewong et al, (1995) di dalam Puspasari, (2013) yang menyatakan bahwa Gnathostoma sp. pada stadium ketiga memiliki bentuk tubuh silinder bukan cacing merah, bentuk kepala menyerupai bola lampu dan diujungnya terdapat sepasang bibir. Pada bagian tubuh dikelilingi oleh duri halus, pada bagian posterior jarak duri semakin renggang, serta banyak duri kecil di ujung posterior. Parasit ini mampu menginvasi saluran pencernaan hewan yang menjadi inangnya karena terlindungi oleh lapisan kutikula. Gnathostoma sp. merupakan salah satu jenis dari nematoda parasitik yang terdapat pada hewan karnivora sebagai inang definitifnya. Gnathostoma sp. sering ditemukan di lingkungan tropis basah terutama di wilayah Asia Tenggara.

Adapun kista yang menginfeksi organ hati dan bentuk kista dari cacing Gnathostoma sp. dapat di lihat pada Gambar 1. Sedangkan identifikasi secara morfologi larva stadium ketiga (L3) Gnathostoma sp. dari hasil pengamatan dengan menggunakan mikroskop trinokuler dapat di lihat pada Gambar 2. 


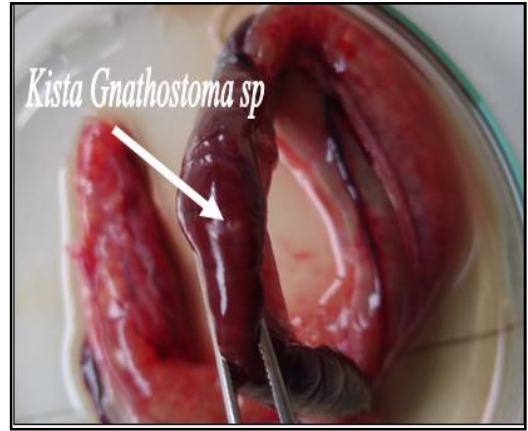

(1)

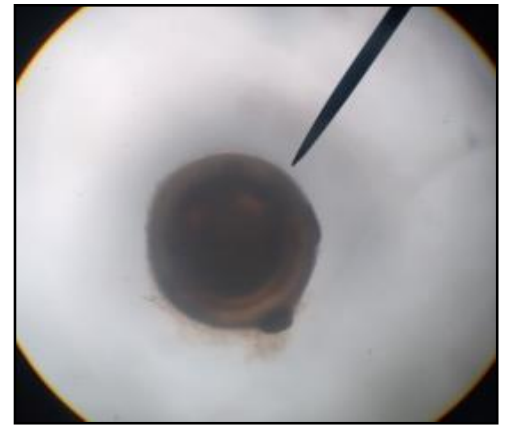

(2)

Gambar 1. Kista di dalam organ hati (1), Kista Gnathostoma sp. (2)

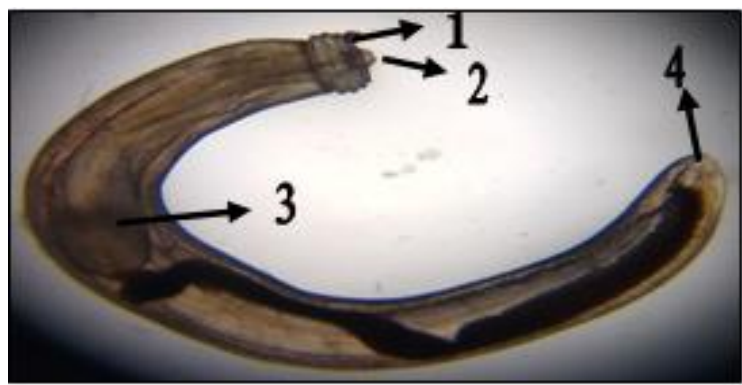

Gambar 2. Larva stadium ketiga (L3) Gnathostoma sp.

Keterangan :

1. Bagian kepala,

2. Bagian mulut dan 2 bibir

3. Bagian esophagus,

4. Bagian anus

Inang antara yang terinfeksi cacing Gnathostoma sp. tidak menunjukkan adanya tanda atau gejala klinis. Hal ini terlihat pada contoh uji penelitian yang menunjukkan tidak ada tanda klinis eksternal pada belut dan ini tentu akan menyulitkan dalam mendeteksi adanya serangan parasit pada belut, namun demikian jika dilakukan pembedahan dan pengamatan pada organ target dari parasit, keberadaan dari cacing Gnathostoma sp. akan dapat diketehui. Hal ini sesuai dengan Rusnak dan Lucey, (1993) di dalam Puspasari, (2013) yang menyatakan bahwa hewan yang memakan inang larva tahap kedua (L2) cacing
Gnathostoma sp. akan terinfeksi dan larva akan bermigrasi ke organ ginjal, hati, dan otot daging dari inang antara kedua untuk berkembang menjadi larva tahap ketiga (L3) dan mengkista di dalam organ tersebut.

Inang antara yang terinfeksi cacing Gnathostoma sp. tidak menunjukkan gelaja klinis khusus. Hal ini dikarenakan cacing Gnathostoma sp. masih dalam tahap perkembangan dan hidup di beberapa hewan yang dijadikan sebagai inang antara (multi inang).

Cacing Gnathostoma sp. memiliki siklus hidup multi inang atau dapat hidup pada beberapa mahluk hidup yang dapat 
dijadikan inangnya. Siklus Gnathostoma sp. dimulai dari telur yang dikeluarkan oleh cacing dewasa ke lingkungan perairan kemudian telur akan menetas dan berkembang menjadi larva tahap pertama (L1). Larva tahap pertama (L1) yang termakan kemudian akan menembus dinding lambung dan berkembang menjadi larva tahap kedua (L2). Hewan yang memakan inang larva tahap kedua (L2) akan terinfeksi dan larva akan bermigrasi ke organ ginjal, hati, dan otot daging dari inang antara kedua untuk berkembang menjadi larva tahap ketiga (L3) dan mengkista.

Tahap akhir dari siklus tersebut jika inang antara kedua termakan oleh inang definif yang merupakan hewan karnivora maka cacing Gnathostoma $s p$ akan berkembang menjadi cacing dewasa dan kemudian akan mengalami keberlajutan dari siklus hidup cacing Gnathostoma $s p$. tersebut.

\section{Prevalensi}

Hasil penelitian menunjukkan bahwa prevalensi Gnathostoma sp. yang menginfeksi organ hati dari belut sawah pada 3 (tiga) farm dan grade yang berbeda dapat di lihat pada Tabel 5. Sementara itu, nilai prevalensi Gnathostoma sp. pada ukuran grade yang berbeda dapat di lihat pada Tabel 6.

Tabel 5. Perbandingan nilai prevalensi Gnathostoma sp. yang menginfeksi belut sawah (Monopterus albus) pada farm dan grade yang berbeda.

\begin{tabular}{|c|c|c|c|c|}
\hline \multirow{2}{*}{$\begin{array}{l}\text { Lokasi } \\
\text { Pengambilan } \\
\text { Sampel }\end{array}$} & \multirow[b]{2}{*}{ Grade } & \multicolumn{2}{|c|}{ Jumlah Sampel } & \multirow[b]{2}{*}{ Prevalensi (\%) } \\
\hline & & $\begin{array}{c}\text { Yang } \\
\text { Diperiksa }\end{array}$ & $\begin{array}{c}\text { Terinfeksi } \\
\text { Gnathostoma sp }\end{array}$ & \\
\hline \multirow[t]{4}{*}{ Farm Nor Aini } & A & 10 & 3 & 30 \\
\hline & B & 10 & 2 & 20 \\
\hline & $\mathrm{C}$ & 10 & 6 & 60 \\
\hline & $\mathrm{D}$ & 10 & 2 & 20 \\
\hline \multirow{4}{*}{$\begin{array}{l}\text { Farm } \\
\text { CV. Karya } \\
\text { Bersama }\end{array}$} & A & 10 & 3 & 30 \\
\hline & B & 10 & 3 & 30 \\
\hline & $\mathrm{C}$ & 10 & 4 & 40 \\
\hline & $\mathrm{D}$ & 10 & 4 & 40 \\
\hline \multirow{4}{*}{$\begin{array}{l}\text { Farm } \\
\text { Saberiannor }\end{array}$} & A & 10 & 6 & 60 \\
\hline & B & 10 & 4 & 40 \\
\hline & $\mathrm{C}$ & 10 & 2 & 20 \\
\hline & $\mathrm{D}$ & 10 & 3 & 30 \\
\hline
\end{tabular}

Sumber : Data primer diolah (2021)

Hasil pemeriksaan contoh uji menunjukkan nilai prevalensi Gnathostoma $s p$. pada belut sawah grade A sebesar $40 \%$, grade $\mathrm{B}$ sebesar $30 \%$, grade $\mathrm{C}$ sebesar $40 \%$, dan grade $\mathrm{D}$ sebesar $30 \%$. Hal ini sesuai dengan Djazuli, $d k k$, (2012) yang menyatakan bahwa belut yang terdapat di Indonesia cenderung terkena infeksi dari parasit Gnathostoma sp. berdasarkan penelitian yang telah dilakukan dengan jumlah contoh uji sebanyak 127 ekor mulai ukuran 17 gram-120 gram ditemukan 35 ekor yang positif Gnathostoma sp. sehingga nilai prevalensi yang didapatkan sebesar $28 \%$. 
Tabel 6. Perbandingan nilai prevalensi Gnathostoma sp. yang menginfeksi belut sawah (Monopterus albus) pada ukuran (grade) yang berbeda.

\begin{tabular}{cccc}
\hline \multirow{2}{*}{ Grade } & \multicolumn{2}{c}{ Jumlah Sampel } & Prevalensi (\%) \\
\cline { 2 - 3 } & Yang Diperiksa & Terinfeksi Gnathostoma sp & 40 \\
A & 30 & 12 & 30 \\
B & 30 & 9 & 40 \\
C & 30 & 12 & 30 \\
D & 30 & 9 &
\end{tabular}

Sumber : Data primer diolah (2021)

Berdasarkan hasil pemeriksaan yang dilakukan terhadap 120 ekor belut sawah diperoleh hasil 42 ekor belut yang positif terinfeksi larva tahap ketiga (L3) Gnathostoma sp. Nilai prevalensi Gnathostoma sp. yang menginfeksi belut sawah dari grade A dan B sebesar $40 \%$, grade $\mathrm{C}$ dan $\mathrm{D}$ sebesar $30 \%$ maka hal ini termasuk dalam kategori commonly atau biasa yang menggambarkan bahwa parasit tersebut biasa menginfestasi ikan dengan kisaran nilai prevalesi sebesar 30-49\%. Hal ini sesuai dengan Williams and Williams, (1996) di dalam Kurniawan, (2016) yang menyatakan bahwa kategori commonly atau biasa menggambarkan bahwa parasit tersebut biasa menginfestasi ikan jika kisaran nilai prevalesi yang didapatkan sebesar 30-49\%.

Cacing Gnathostoma sp. biasa menginfeksi belut sawah dapat dipengaruhi oleh banyak hal. Salah satunya adalah kondisi lingkungan perairan yang buruk sebagai tempat hidupnya. Hal ini diduga karena banyaknya aktivitas manusia, hewanhewan ternak, maupun hewan liar di sekitar area persawahan yang dapat menghasilkan bahan organik. Bahan organik tersebut akan larut dan mengendap di dasar perairan sawah akibat air hujan pada musim penghujan sehingga bahan organik akan mengalir ke perairan sawah. Tingginya kandungan bahan organik akan berdampak pada suburnya perairan sawah dan menyebabkan munculnya parasit nematoda salah satunya dari jenis Gnathostoma sp. yang berasal dari hewan liar sehingga dapat menginfeksi (transmisi) ke organ dalam belut sawah melalui pakan alami yang berada di perairan sawah. Hal ini sesuai dengan Damanik, $d k k$ (2019) yang menyatakan bahwa kegiatan manusia seperti persawahan dan peternakan kerbau, serta hewan liar akan menghasilkan limbah organik. Pada musim hujan limbah organik akan mengalir ke perairan sawah dan mengendap di dasar perairan sehingga menghasilkan substrat lumpur. Tingginya bahan organik ditambah dengan penggunaan pestisida akan mengganggu kualitas air. Jika hal ini terjadi terus menerus maka kualitas air akan turun, belut akan menjadi stres, dan mudah terserang penyakit terutama dari golongan parasit.

Selain itu, peran dari organisme kecil seperti crustacea yang merupakan makanan bagi belut sawah sekaligus sebagai inang antara pertama juga turut mempengaruhi keberadaan dari Gnathostoma sp. di dalam tubuh belut. Hal ini sesuai dengan Ulkhaq (2020) yang menyatakan bahwa terjadinya infeksi cacing endoparasit pada belut disebabkan mengkonsumsi pakan alami yang mengandung larva cacing Gnathostoma sp. Pakan alami yang mengandung larva cacing Gnathostoma $s p$ akan berpindah/ transmisi dari pakan ke dalam tubuh belut. Hal ini akan menyebabkan belut terinfeksi dan menjadi inang antara kedua dari cacing endoparasit tersebut. Menurut Khati $d k k$ (2013) menyatakan bahwa infeksi tertinggi cacing Gnathostoma sp. pada belut terjadi pada bulan Juni sampai Oktober yaitu pada musim hujan dan infeksi parasit tersebut 
mengalami penurunan secara signifikan setelah berakhirnya musim hujan.

Berdasarkan gambaran dari hasil pemeriksaan sampel contoh uji belut sawah serta nilai prevalensi yang didapatkan. Hal tersebut tidak memiliki pengaruh terhadap pengiriman belut sawah keluar Provinsi Kalimantan Selatan untuk lokal maupun ekspor. Hal ini dikarenakan belum ada aturan yang mengatur tentang larangan pengiriman antar area untuk belut sawah yang positif terinfeksi parasit Gnathostoma $s p$. Sementara itu, setelah negara Tiongkok mencabut syarat dalam hal pemasukan belut wajib bebas dari parasit Gnathostoma sp. serta tidak ada negara lain mempersyaratkannya, maka untuk pengiriman ekspor juga masih dapat dilakukan meskipun hasil pemeriksaan contoh uji menunjukkan adanya infeksi dari parasit Gnathostoma sp. tersebut. Hal ini

\section{KESIMPULAN DAN SARAN}

a. Infeksi larva stadium ketiga (L3) cacing Gnathostoma sp. ditemukan menempel di organ hati pada contoh uji belut sawah (Monopterus albus) untuk setiap ukuran (grade) A, B, C, dan D di 3 (tiga) farm yang berbeda.

b. Dari hasil pengujian belut sawah (Monopterus albus) dengan ukuran yang berbeda didapatkan nilai prevalensi grade A dan gade $\mathrm{C} 40 \%$, grade $\mathrm{B}$ dan grade $\mathrm{D}$ $30 \%$. Dapat disimpulkan bahwa larva sesuai dengan pedoman yang dikeluarkan oleh Pusat Karantina Ikan dan Keamanan Hayati Ikan (2016) yang menjelaskan bahwa parasit Gnathostoma sp. tidak masuk ke dalam penyakit ikan yang wajib bebas pada produk aquatik untuk pengiriman ikan ke luar negeri (ekspor).

Parasit Gnathostoma sp. merupakan parasit yang bersifat zoonosis maka perlu hati-hati dalam penanganannya. Pencegahan terjadinya penyebaran parasit Gnathostoma $s p$. ke daerah lain dapat dilakukan dengan cara pemeriksaan secara laboratorium pada sampel belut sawah yang akan dikirim ke luar wilayah Provinsi Kalimantan Selatan maupun ke luar negeri (ekspor) serta memasukkan parasit Gnathostoma sp. ke dalam peraturan yang mengatur tentang larangan pengiriman belut jika pada sampel uji menunjukkan adanya infeksi parasit Gnathostoma sp.

stadium ketiga (L3) cacing Gnathostoma $s p$. biasa menginfeksi belut sawah (Monopterus albus) yang ada di Provinsi Kalimantan Selatan.

c. Pengiriman belut sawah ke luar Provinsi Kalimantan Selatan masih dapat dilakukan meskipun hasil pemeriksaan sampel contoh uji menunjukkan adanya infeksi parasit Gnathostoma sp. 


\section{Saran}

Dengan ditemukannya infeksi cacing Gnathostoma sp. pada organ hati belut sawah (Monopterus albus) maka perlu upaya dalam pengendalian penyebaran penyakit ke daerah lain di luar Provinsi Kalimantan Selatan dengan membuat peraturan yang mengatur tentang larangan pengiriman belut untuk lokal maupun ekspor jika pada sampel uji menunjukkan adanya infeksi parasit Gnathostoma sp. serta perlu penelitian lebih lanjut dalam menanggulangi infeksi parasit Gnathostoma sp. pada belut sawah. Hal ini dikarenakan parasit Gnathostoma sp. bersifat zoonosis atau mampu berpindah (transmisi) ke manusia.

\section{DAFTAR PUSTAKA}

Damanik, Suci Anggeraini. Deni Efizon. Efawani. 2019. Jurnal Pola Lingkaran Pada Pertumbuhan Otolith Belut (Monopterus albus Zuiew) Di Rawa Desa Sawah Kabupaten Kampar Provinsi Riau. Fakultas Perikanan Dan Kelautan. Universitas Riau. Pekan Baru.

Djazuli, Nazori,. Yulianti H. Sipahutar,. Dan Saiful A Torada. 2012. Pengamatan Parasit Gnathostoma (Nematoda : Gnathostomatidae) Pada Belut (Synbranchidae) Hidup. Prosiding Seminar Nasional Perikanan Indonesia 13-14 November 2012. Sekolah Tinggi Perikanan, Jakarta.

Keputusan Kepala BKIPM Nomor 117 Tahun 2017 tentang Petunjuk Teknis Pengambilan Contoh Uji Media Pembawa. Badan Karantina Ikan Dan Pengendalian Mutu Hasil Perikanan. Jakarta

Khati, Syauli Ashari,. Radith Mahatma,. Windarti. 2013. Parasit Pada Belut Sawah (Monopterus albus, Zuiew 1793) Di Desa Sawah Kecamatan
Kampar Utara. Penelitian. Universitas Binawidya Pekanbaru.

Kurniawan, Muhammad Rizki. 2016. Laporan Skripsi Identifikasi Dan Prevalensi Cacing Saluran Pencernaan Pada Belut Rawa (Synbranchus bengalensis) Yang Dipasarkan Di Kota Surabaya Jawa timur. Fakultas Perikanan Dan Kelautan Universitas Airlangga. Surabaya.

Lusiastuti, Angela Mariana., Riza Tiuria., Agustin Indrawati., dan Uni Purwaningsih. 2013. Cacing Nematoda Pada Belut, Monoterus albus : Pencegahan dan Pengendalian Gnathostomiasis. Prosiding Forum Inovasi Teknologi Akuakultur 2013.

Purwanto, Agus Erwan, Dyah Ratih Sulistyastuti. 2017. Metode Penelitian Kuantitatif Untuk Administrasi Publik Dan MasalahMasalah Sosial. DIY Yogyakarta : Penerbit Gava Media.

Pusat Karantina Ikan Dan Keamanan Hayati Ikan. 2016. Persyaratan Ekspor Ke Negara Tujuan. Jakarta

Puspasari, Khumaira. 2013. Tesis Karakterisasi Protein Antigenik Larva 3 Gnathostoma Spinigerum Pada Ikan Belut Rawa (Monopterus alba) Menggunakan Teknik Immunoblotting. Sekolah Pasca Sarjana Institut Pertanian Bogor. Bogor.

Rokhmah, Siti Alfaniatur., Yuyun Suprapti., dan Miftachul Munir. 2019. Karakteristik Istri Nelayan Dalam Upaya Meningkatkan Pendapatan Keluarga Pesisir Pantura Di Desa King-King Kecamatan Tuban 
Kabupaten Tuban. Jurnal Ilmiah Perikanan Dan Kelautan Volume 11. No 1. April (2019).

Ulkhaq, Mohammad Faizal. 2020. Derajat Infeksi Cacing Nematode Endoparasit Pada Belut Sawah Dari
Kabupaten

Banyuwangi. https://fpk.unair.ac.id/derajat-infeksicacing-nematode-endoparasit-padabelut-sawah-dari-kabupatenbanyuwangi/. 20 Mei 2020. Diakses Tanggal 19 Januari 2021 